\title{
An IL-12/Shh-C domain fusion protein-based IL-12 autocrine loop for sustained natural killer cell activation
}

\author{
LINING ZHU ${ }^{1}$, ZHIHUI ZHAO ${ }^{2}$, YANZHANG WEI ${ }^{1}$, WILLIAM MARCOTTE $\mathrm{Jr}^{3}$, \\ THOMAS E. WAGNER ${ }^{4}$ and XIANZHONG YU ${ }^{1}$ \\ ${ }^{1}$ Department of Biological Sciences, Clemson University, Clemson, SC 29634, USA; \\ ${ }^{2}$ Department of Animal Genetics and Breeding, Jilin University, Changchun 130062, P.R. China; \\ ${ }^{3}$ Department of Genetics and Biochemistry, Clemson University, Clemson, SC 29634; \\ ${ }^{4}$ Orbis Health Solutions, Greenville, SC 29607, USA
}

Received January 31, 2012; Accepted March 2, 2012

DOI: 10.3892/ijo.2012.1466

\begin{abstract}
The dependency of activated natural killer (NK) cells on the continuous support of exogenous interleukin (IL)-2 for their in vivo survival, tumor localization and consequently, their antitumor effect, is a major obstacle for NK cell-mediated tumor therapy. In the present study, a fusion gene between IL-12 and mouse sonic hedgehog C-terminal domain (Shh-C) was constructed. The fusion protein was autocatalytically processed to form cholesterol-modified IL-12 molecules and an autocrine loop of IL-12 was established for the sustained activation of NK cells. The transduced NK cells matured more rapidly in vitro with the enhanced expression of granule-related proteins. $\mathrm{NK}_{\mathrm{IL}-12 / \mathrm{Sh} h-\mathrm{C}}$ cells reached the same proliferation rate as NK cells transduced with enhanced green fluorescent protein (EGFP)/Shh-C ( $\left.\mathrm{NK}_{\mathrm{EGFP} / \text { Shh-C }}\right)$ with < 10 -fold IL-2 supplementation, suggesting that the fusion protein reduced the dependency of NK cells on IL-2. The amount of interferon- $\gamma($ IFN- $\gamma)$ in the supernatants of $\mathrm{NK}_{\mathrm{IL}-12 / \mathrm{Shh}-\mathrm{C}}$ cells 5 and 7 days after transduction was significantly higher than that in the supernatants of $\mathrm{NK}_{\mathrm{IL}-12}$ cells. Immunofluorescent staining of lung tissues from B16-bearing mice which had received an intravenous injection of lentivirus-transduced NK cells without exogenous IL-2 confirmed that donor NK cells successfully infiltrated into the lung tissues. The survival time of the mice which had received $\mathrm{NK}_{\mathrm{IL}-12 / \mathrm{Sh} \text {-C }}$ cells was significantly prolonged compared to the mice which had received $\mathrm{NK}_{\mathrm{EGFP} / S h h-\mathrm{C}}$ cells.
\end{abstract}

Correspondence to: Dr Xianzhong Yu, Department of Biological Sciences, 132 Long Hall, Clemson University, Clemson, SC 29634, USA

E-mail: xyu@clemson.edu

Key words: interleukin-12, sonic hedgehog C-terminal domain, fusion, autocrine, natural killer cells, activation

\section{Introduction}

As an integral part of the innate immune system, natural killer (NK) cells respond rapidly to infectious diseases and malignant transformation to restrict the dissemination of diseases and to elicit the long-lasting, antigen-specific adaptive immune reactions (1). Numerous studies have illustrated that NK cells can effectively control tumor growth through perforin (2) and cytokines (3). The critical role of NK cells in anti-tumor immunity has been further demonstrated by clinical studies showing that patients with dysfunctional NK cells have an increased risk of developing leukemia (4).

Normal NK cells are usually not found in the cell cycle; they are found only in response to infection from certain pathogens or to the stimulation with high doses of appropriate cytokines [type I interferons (IFNs), interleukin (IL)-2, IL-12 or IL-15] (5). The early pioneering study on lymphokine-activated killer cell-based immunotherapy by Rosenberg was based on this protocol (6). Current techniques for activating NK cells are all based on cytokines, usually with high doses which are not well-tolerated by the host. IL-2 is known as the growth factor for both T lymphocytes and NK cells, and potentially enhances the cytotoxicity of these cells as well. Resting NK cells from humans and mice respond readily to recombinant IL-2 (rIL-2) stimulation, without the help of accessory cells and co-factors (7). It has been suggested that the in vivo survival, tumor localization, and consequently, the antitumor effect of the activated NK (A-NK) cells are strongly dependent on the continuous support of relatively high doses of exogenous IL-2 (8). It has been shown that optimal tumor localization and antitumor activity of the adoptively transferred NK cells are difficult to achieve even when IL-2 was systemically administered every $4 \mathrm{~h}$ for 3 consecutive days due to the short in vivo half-life of IL-2 ( 6.9 $\mathrm{min})(9)$. When long-lived (0.5 to $4 \mathrm{~h}$ ) polyethylene glycol-conjugated IL-2 (PEG-IL-2) was used, tumor localization and antitumor activity were substantially improved (10). Other cytokines, such as IL-12 (11), IL-15 and IL-21, which strongly augment NK cell proliferation and effector functions, have also been used to substitute for IL-2. However, all the cytokines systemically used in vivo have been associated with dose-related toxicity (12). It is clear that an alternative has to 
be found to circumvent the demand of A-NK cells for exogenous IL-2 to sustain their activities before adoptive NK cell transfer can be clinically feasible.

The adenovirus transduction of A-NK cells with IL-12 not only can enhance their antitumor effectiveness but can also reduce their reliance on systemically administered IL-2 (8). However, the expression of IL-12 in NK cells may still have the potential to cause a systemic IL-12 effect. In a mouse B16 tumor model, the direct delivery of IL-12 to the tumor site maintained its anticancer activity but avoided much of the toxic side-effects (13). The co-transfection of tumor cells with GPI-anchored IL-2 and IL-12 has been shown to synergistically enhance the antitumor effect and to have less adverse effects (14). It has also been reported that endoplasmic reticulum-restricted IL-2 offers autocrine growth stimulation to NK-92 cells (15). In this study, we designed a fusion gene between mouse sonic hedgehog $(\mathrm{Hh})$ C-terminal (Shh-C) auto-processing domain and IL-12 (IL-12/ Shh-C) as a self-supporting autocrine system to reduce or eliminate the dependency of NK cells on exogenous cytokines and sustain their activated status.

Hh family proteins have been shown to play essential roles in cell fate specification during development. As morphogens, they are produced from localized sites and spread through the extracellular matrix to form a gradient and determine cell fates through multiple regulations in a concentration-dependent manner (16-21). The Hh precursor protein undergoes internal proteolysis between Gly-Cys residues to confer cholesterol modification at its carboxy terminus and palmitoylation modification at its amino terminus (22). The cholesterol moiety serves as a membrane-anchorage to restrict long-range signaling and unregulated spreading, thus increasing local Shh concentration (23). It has been demonstrated that Shh-C can direct green fluorescent protein (GFP) to the cell membrane with a cholesterol tail attached (24). The results from the present study show that mouse NK cells transduced with lentiviruses encoding this IL-12/ Shh-C fusion gene have significantly reduced dependency on IL-2 in vitro. Also, prolonged survival was observed when ex vivo A-NK cells transduced with IL-12/Shh-C lentivirus were adoptively transferred to B16 melanoma tumor-bearing mice.

\section{Materials and methods}

Fusion gene construction and lentivirus production. Eleven-day mouse embryo total RNA was purchased from Clontech. cDNA was generated by reverse transcription with a RetroScript kit (Ambion). Mouse Shh-C was PCR-amplified and cloned into the pCR2.1 vector (Invitrogen). Mouse mIL-12 fragment without stop codon was amplified with PCR using the pORFmIL-12 plasmid (Invivogen) as the template. The enhanced GFP (EGFP) fragment without stop codon was PCR-amplified with pIRES-EGFP (Clontech) as the template. Both mIL-12 and EGFP fragments were subcloned into pCDH-EF1-MCS (System Biosciences) to construct the plasmid pCDH-EGFP and pCDH-fusion-IL-12. pCDH-ORF-mIL-12 was generated by ligation of pCDH-EF1-MCS digested with $S w a I$ and pORFmIL-12 treated with SwaI and EcoRV.

The calcium phosphate transfection method was used in lentivirus production. $293 \mathrm{TN}$ cells were seeded at the density of $7 \times 10^{6}$ cells per T-150 flask one day before transfection without antibiotics. Different lentiviral expression vectors $(40 \mu \mathrm{g})(\mathrm{pCDH}-$
EGFP, pCDH-ORF-mIL-12 and pCDH-fusion IL-12) were mixed with pMDLg/pRRE, pRSV-Rev and pMD2.G (Addgene) and used for co-transfection of 293TN cells. Forty-eight hours post-transfection, supernatant containing recombinant lentiviral particles was clarified with $0.45 \mu \mathrm{m}$ filter (Corning) and stored at $-80^{\circ} \mathrm{C}$. Lentivirus was titered by $\mathrm{CHO}$ cell transduction. Briefly, $1 \times 10^{5} \mathrm{CHO}$ cells were plated into 24 -well plate and lentivirus was added with various dilution factors of $10^{-2}$ to $10^{-1}$ in the presence of $8 \mu \mathrm{g} / \mathrm{ml}$ of polybrene (Sigma-Aldrich). After 1-h centrifugation at 1,200 x g, the cells were incubated for $5 \mathrm{~h}$ at $37^{\circ} \mathrm{C}$ and $5 \% \mathrm{CO}_{2}$. Four days after transduction, biological titer was calculated by the following equation as previously described (27): transduction unit $(\mathrm{TU} / \mathrm{ml})=(\%$ of GFP- or IL-12 positive cells $\mathrm{x}$ number of cells at time of transduction) $\mathrm{x}$ dilution factor/ (100x volume of lentivirus added).

Mice and tumor cell lines. Female C57BL/6 mice and congenic B6.PL-Thyla/CyJ mice, purchased from Jackson Laboratory, at age 8-20 weeks were used for the present study, and all experiments were carried out with approval from the Institutional Animal Care and Use Committee. The murine melonoma cell line, B16, was obtained from ATCC. B16 cells were maintained in RPMI-1640 (Hyclone) with 10\% heat-inactivated fetal bovine serum (FBS), 2 mM of glutamine and antibiotics.

NK cell isolation and lentiviral transduction. Congenic B6.PL-Thyla/CyJ mice were sacrificed and spleen tissues were homogenized by grinding the tissues with 2 frosted glass slides. After filtering through a cell strainer of $40 \mu \mathrm{m}$ (BD Biosciences) to obtain a single cell suspension, spleen cell were centrifuged at $300 \mathrm{x}$ g for $15 \mathrm{~min}$. Erythrocytes were lysed by ACK lysing buffer (Lonza). The splenic lymphocytes were then subjected to magnetic labeling and separation by using a Natural Killer Cell Isolation kit (Miltenyi Biotec). The purity of freshly isolated NK cells from the spleen was $>90 \% \mathrm{NK} 1.1^{+},<6 \%$ $\mathrm{CD}^{+}$. NK cells were cultured in RPMI-1640 medium (Hyclone) supplemented with $10 \%$ heat-inactivated FBS (Hyclone), $50 \mu \mathrm{M}$ $\beta$-mercaptoethanol, $2 \mathrm{mM}$ glutamine, and $1 \mathrm{X}$ non-essential amino acids. For activation and expansion purposes, 6,000 IU/ $\mathrm{ml}$ of recombinant human IL-2 (rhIL-2) (Peprotech) was added every other day. Seven-day rhIL-2-stimulated NK cells were plated into 48 -well plates at $2 \times 10^{5}$ cells $/ 250 \mu \mathrm{l}$ per well. NK cells were transduced at $1 \mathrm{MOI}$ in the presence of $5 \mu \mathrm{g} / \mathrm{ml}$ polybrene (Sigma-Aldrich) by centrifugation at $1,200 \mathrm{x} \mathrm{g}$ for $1 \mathrm{~h}$. After centrifugation, transduced NK cells were incubated at $37^{\circ} \mathrm{C}$ and $5 \% \mathrm{CO}_{2}$ for an additional $4 \mathrm{~h}$ then replaced with complete culture medim. The following day, lentiviral transduction was repeated on the transduced NK cells.

NK cell proliferation assay. NK cells were transduced with EGFP/Shh-C, IL-12 or IL-12/Shh-C lentiviruses at an MOI of 1 on both days 7 and 8 after isolation. Three days after double transduction, 15,000 $\mathrm{NK}_{\mathrm{EGFP} / \mathrm{Shh}-\mathrm{C}}, \mathrm{NK}_{\mathrm{IL}-12}$ and $\mathrm{NK}_{\mathrm{IL}-12 /}$ Sh-C cells were plated per well in 96-well plates with $100 \mu \mathrm{l}$ of culture medium, supported with $0,60,600$ and 6,000 IU/ml of IL-2. IL-2 was added every other day. Proliferation assays were performed 24, 48, 72 and $96 \mathrm{~h}$ after plating. AlamarBlue (Invitrogen) reagent was added in an amount equal to $10 \%$ of the culture volume. After being cultured for $4.5 \mathrm{~h}$ at $37^{\circ} \mathrm{C} / 5 \% \mathrm{CO}_{2}$, the absorbance was measured at a wavelength of $560 \mathrm{~nm}$ with 
a reference of $620 \mathrm{~nm}$. The cell numbers were determined by using a standard curve. All samples were run in triplicate.

Analysis of NK cell markers by flow cytometry. EGFP expression was directly detected by comparing transduced versus non-transduced NK cells. Antibodies for surface marker analysis of NK cells for anti-NK1.1, CD3, CD25 and CD11b were all from BD Pharmingen. For intracellular staining, anti-IL-12 p40, perforin and ganzyme B were obtained from eBioscience. Prior to staining with antibodies, mouse BD Fc Block (BD Biosciences) was used to prevent non-specific binding. All samples were fixed with BD Cytofix ${ }^{\mathrm{TM}}$ Fixation Buffer (BD Biosciences) and then stored in phosphate-buffered saline supplemented with $2 \%$ FBS and $0.2 \%$ sodium azide (Sigma). For intracellular staining, samples were fixed then permeabilized with BD Cytoperm ${ }^{\mathrm{TM}}$ Permeabilization Buffer (BD Biosciences) prior to antibody staining. A minimum of 15,000 cells were used in all samples. Data acquisition was performed on a Guava EasyCyte Mini system (Guava Technologies) and analyzed by FACS Express 2 software. Data obtained from quadrant gating were compared to the non-transduced control group.

Cytokine production analysis. Supernatants from overnight NK cell cultures 7 days after lentiviral infection and serum from experimental mice were used to determine IFN- $\gamma$, IL-12 and tumor necrosis factor- $\alpha$ (TNF- $\alpha$ ) levels. Mice serum from each group was collected from the tail vein at 3, 7 and 14 days after the adoptive transfer of NK cells. The mouse IFN- $\gamma$ ELISA Ready-SET-Go kit, the mouse IL-12/IL-23 total p40 ELISA Ready-SET-Go kit and the mouse TNF- $\alpha$ ELISA Ready-SET-Go kit (eBioscience) were used according to manufacturer's instructions.

NK cell cytotoxicity assay. Mouse lymphoma YAC-1 cells were used as the target and stained with $0.5 \mu \mathrm{M}$ Guava CFSE (Guava Technologies) per $2.5 \times 10^{6}$ cells. Triplicate wells of NK cells were mixed with YAC-1 cells in 96-well round bottom plates to yield effector cell to target cell (E:T) ratios of 2:1, 1:1, 0.5:1 and $0.2: 1$. The plates were centrifuged at $50 \mathrm{x}$ g for $2 \mathrm{~min}$ prior to 4 -h incubation at $37^{\circ} \mathrm{C}$ and $5 \% \mathrm{CO}_{2}$. Subsequently, $50 \mu \mathrm{l}$ of Guava Express 7-AAD (Guava Technologies) per $1 \times 10^{5}$ cells were added into each well. Five thousand events were acquired for each sample. YAC-1 cells only were used as the control for spontaneous cell death. The percentage of NK cell cytotoxicity was calculated using the following equation: percentage of specific lysis $=(\%$ dead targets $-\%$ spontaneous dead targets $)$ x 100/(100 - \% spontaneous dead targets).

Adoptive transfer of $N K$ cells. C57BL/6 mice received $3.75 \times 10^{5}$ B16 melanoma tumor cells intravenously (i.v.) to establish pulmonary metastases. Three days later, $5 \times 10^{6} \mathrm{NK}_{\mathrm{EGFP} / \mathrm{Shh}-\mathrm{C}}$ cells, $\mathrm{NK}_{\mathrm{IL}-12}$ cells and $\mathrm{NK}_{\mathrm{IL}-12 / \mathrm{Shh}-\mathrm{C}}$ cells were injected via the lateral tail vein without IL-2 administration.

Analysis of tumor infiltration by NK cells in vivo. Seventy-two hours after adoptive transfer, lung tissues obtained from mice were fresh frozen at $-80^{\circ} \mathrm{C}$ and were then sectioned into $8-\mu \mathrm{m}$ tissue slides. After fixing in $4 \%$ paraformaldehyde, tissues were stained with FITC-conjugated anti-Thy 1.1 Ab (BD Pharmingen) at a 1:200 dilution for $30 \mathrm{~min}$ at room temperature. FITC- conjugated IgG2a (BD Pharmingen) was used as an isotype control. A fluorescent microscope was used to obtain images.

Statistical analysis. Two-tailed, unpaired Student's t-tests were used. For survival experiments, data were analyzed by the Kaplan-Meier method.

\section{Results}

Fusion gene construction and expression. To construct the EGFP/Shh-C and murine IL-12/Shh-C fusion genes, the $\mathrm{N}$-terminal domain of the mouse sonic Hh gene was replaced with EGFP or murine IL-12 (with signal peptides deleted), leaving the conserved cleavage-processing motif, SGGCF, intact. The fusion genes were then cloned into lentiviral expression vectors (Fig. 1A). The fusion genes were successfully expressed and processed in 293TN cells as expected. As shown in Fig. 1B, EGFP was concentrated around the periphery of cells forming fluorescent holo-circles, indicating that the EGFP fusion protein was successfully processed and tethered on the cell membrane. In Fig. 1C, fusion EGFP (52 kDa), processed EGFP (27 kDa), fusion IL-12 (95 kDa) and processed IL-12 (70 kDa) were all detected by western blot analysis.

NK cell transduction by fusion gene recombinant lentiviruses. NK cells were doubly-transduced with EGFP/Shh-C, IL-12 or IL-12/Shh-C recombinant lentiviruses at a MOI of 1 on both days 7 and 8 after in vitro culture. On days 3, 5, 7 and 10 after the second transduction, the transduction rates were assayed with FACS analysis. Cell numbers were determined by trypan blue exclusion assay. All 3 recombinant lentiviruses had similar transduction rates $(\sim 30 \%)$ on day 10 after the second transduction (Fig. 2A). However, NK cells transduced with IL-12 and IL-12/Shh-C recombinant lentiviruses had higher survival/ proliferation rates resulting in significantly higher cell numbers (Fig. 2B)

IL-12 and IL-12/Shh-C fusion proteins enhance NK cell proliferation in vitro. $\mathrm{NK}$ cells untransduced $\left(\mathrm{NK}_{\mathrm{UN}}\right)$ or transduced with different recombinant lentiviruses were plated at a concentration of 15,000 cells/well in a 96-well plate and cultured with different concentrations of IL-2. NK $\mathrm{NL}_{\mathrm{IL}-1 / \mathrm{Shh}-\mathrm{C}}$ cells had a substantially faster growth rate compared to $\mathrm{NK}_{\mathrm{UN}}$ cells and $\mathrm{NK}_{\mathrm{EGFP} / \mathrm{Shh}-\mathrm{C}}$ cells; even when IL-2 was absent, $\mathrm{NK}_{\mathrm{IL}-12 / \mathrm{Shh}-\mathrm{C}}$ cells showed an apparent advantage in expansion compared to $\mathrm{NK}_{\mathrm{UN}}$ cells and $\mathrm{NK}_{\mathrm{EGFP} / \mathrm{Shh}-\mathrm{C}}$ cells at 24 and $96 \mathrm{~h}$ after plating (Fig. 3A-D). However, IL-12 cannot be the sole driving force for NK cell survival in the long-term cultures. The effect of IL-12 was most significant when IL-2 was added at low or medium levels (Fig. 3A-D). NK $\mathrm{IL}_{\mathrm{I} / \mathrm{Shh}-\mathrm{C}}$ cells, when given $<10$-fold addition of IL-2, reached the same cell numbers as $\mathrm{NK}_{\mathrm{EGFP} / S h h-C}$ cells in most cases.

Cytotoxicity of NK cells significantly increased after lentivirus infection. Mouse lymphoma YAC-1 cells were used as the target and stained with $0.5 \mu \mathrm{M}$ Guava CFSE (Guava Technologies) per $2.5 \times 10^{6}$ cells. NK cells were mixed with YAC-1 cells in 96-well round bottom plates to yield E:T ratios of 2:1, 1:1, 0.5:1 and 0.2:1. Five days after double transduction, statistically significant differences between the cytotoxicities 
A
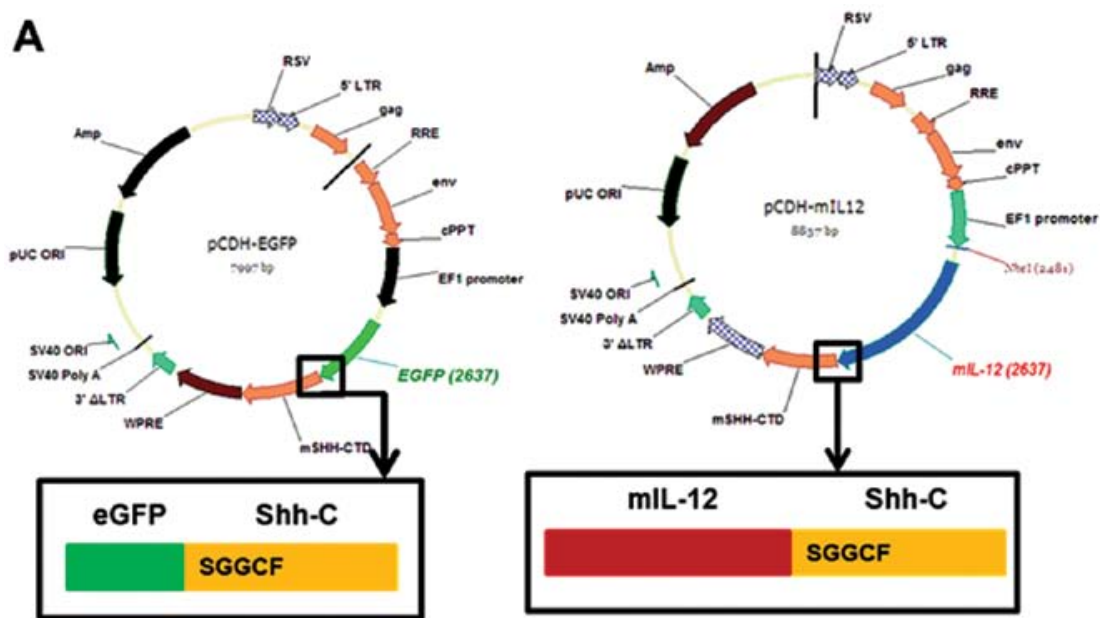

B

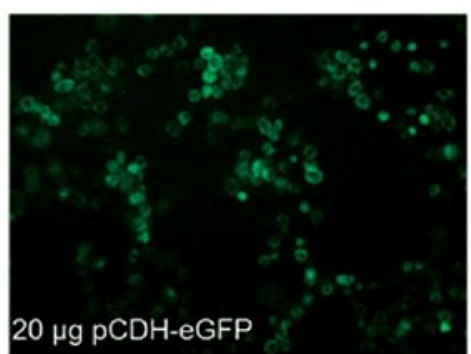

C

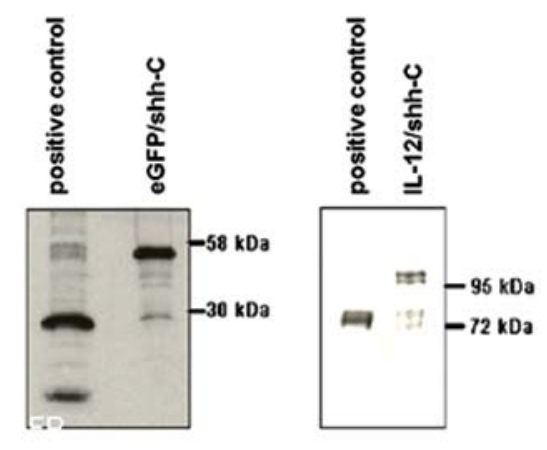

Figure 1. Schematic representation of (A) the cloning strategy and (B) EGFP fusion gene expression in 293TN cells. (C) Both EGFP and murine IL-12 (mIL-12) fusion proteins were processed correctly as shown by western blot analysis. EGFP/Shh-C fusion protein was shown as a 52-kDa band and processed EGFP as a 27-kDa band. For mIL-12/Shh-C fusion, the band size was $95 \mathrm{kDa}$ and the processed mIL-12 was a 70-kDa band. mShh-C, mouse Shh-C.
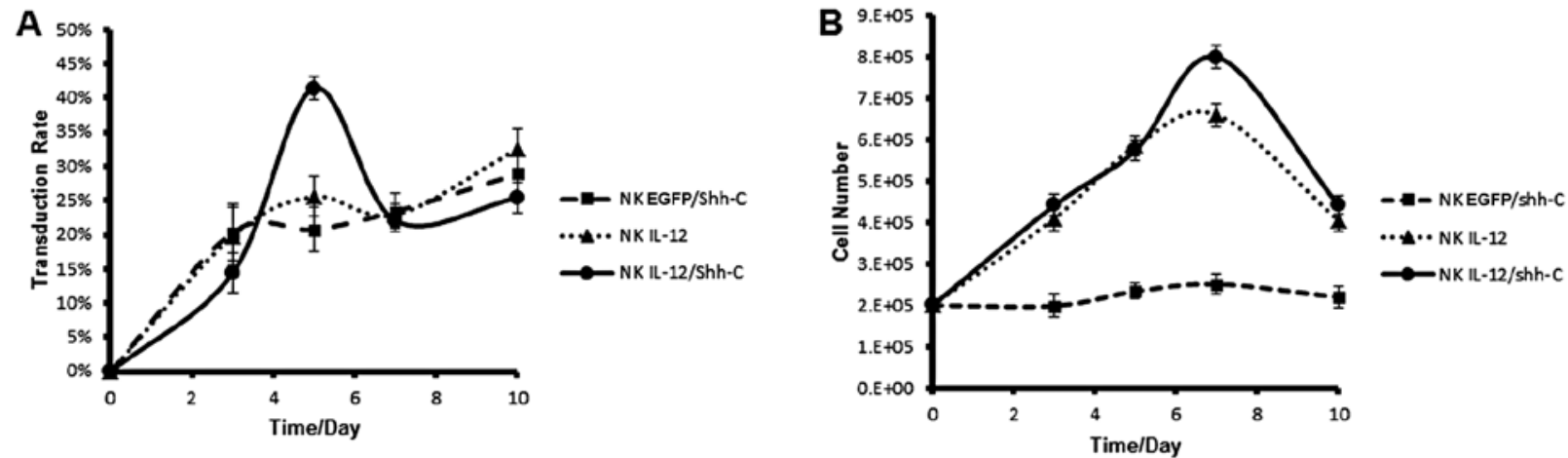

Figure 2. NK cells were doubly-transduced with EGFP/Shh-C, IL-12, or IL-12/Shh-C lentiviruses at an MOI of 1 on days 7 and 8 after in vitro culture. On days 3, 5,7 and 10 after the second transduction, the transduction rates were analyzed with FACS for the expression of EGFP and mIL-12 (p40). Cell numbers were determined by trypan blue exclusion assay. (A) Transduction rate. (B) Cell numbers.

of $\mathrm{NK}_{\mathrm{IL}-12 / \mathrm{Sh}-\mathrm{C}}$ and $\mathrm{NK}_{\mathrm{IL}-12}$ cells were observed at E:T ratios of 1:1 ( $\mathrm{p}=0.00017)$ and 2:1 ( $\mathrm{p}=0.02152)$, as shown in Fig. 4A. Additionally, $\mathrm{NK}_{\mathrm{UN}}$ cells had a significantly lower cytotoxicity than $\mathrm{NK}_{\mathrm{IL}-12 / \mathrm{Shh}-\mathrm{C}}$ cells at E:T ratios of 0.5:1 $(\mathrm{p}=0.00413)$ and $1: 1(\mathrm{p}=0.00026)$. Furthermore, 7 days after double transduction, significantly elevated cytotoxicities of $\mathrm{NK}_{\mathrm{IL}-12 / \mathrm{Sh}-\mathrm{C}}$ cells were observed compared to $\mathrm{NK}_{\mathrm{UN}}$ cells at all E:T ratios, as shown in Fig. 4B. $\mathrm{NK}_{\mathrm{IL}-12}$ cells showed enhanced cytotoxicity at an E:T ratio of 1:1 and 2:1 only, in comparison to the effect of $\mathrm{NK}_{\mathrm{UN}}$ cells.
Phenotypic characterization of recombinant lentivirus-infected $N K$ cells. The percentage of the Mac-1-positive subpopulation in lentivirus-transduced NK cells was significantly higher than that of untransduced NK cells. Statistical analysis showed that $\mathrm{NK}_{\mathrm{IL}-12 / \mathrm{Shh}-\mathrm{C}}$ cells had insignificantly less Mac- ${ }^{\text {hi }}$ population compared with $\mathrm{NK}_{\mathrm{UN}}$ cells and $\mathrm{NK}_{\mathrm{EGFP} / \text { Shh-C }}$ cells at 7 days after lentivirus double transduction. On day $9, \mathrm{NK}_{\mathrm{IL}-12 / \mathrm{Sh} h-\mathrm{C}}$ cells had considerably more Mac- $1^{\text {hi }}$ cells than $\mathrm{NK}_{\mathrm{UN}}$ cells $(\mathrm{p}=0.00515)$ (Fig. 5A). For CD25, all the recombinant lentivirus-transduced NK cells showed significantly higher expression levels compared 

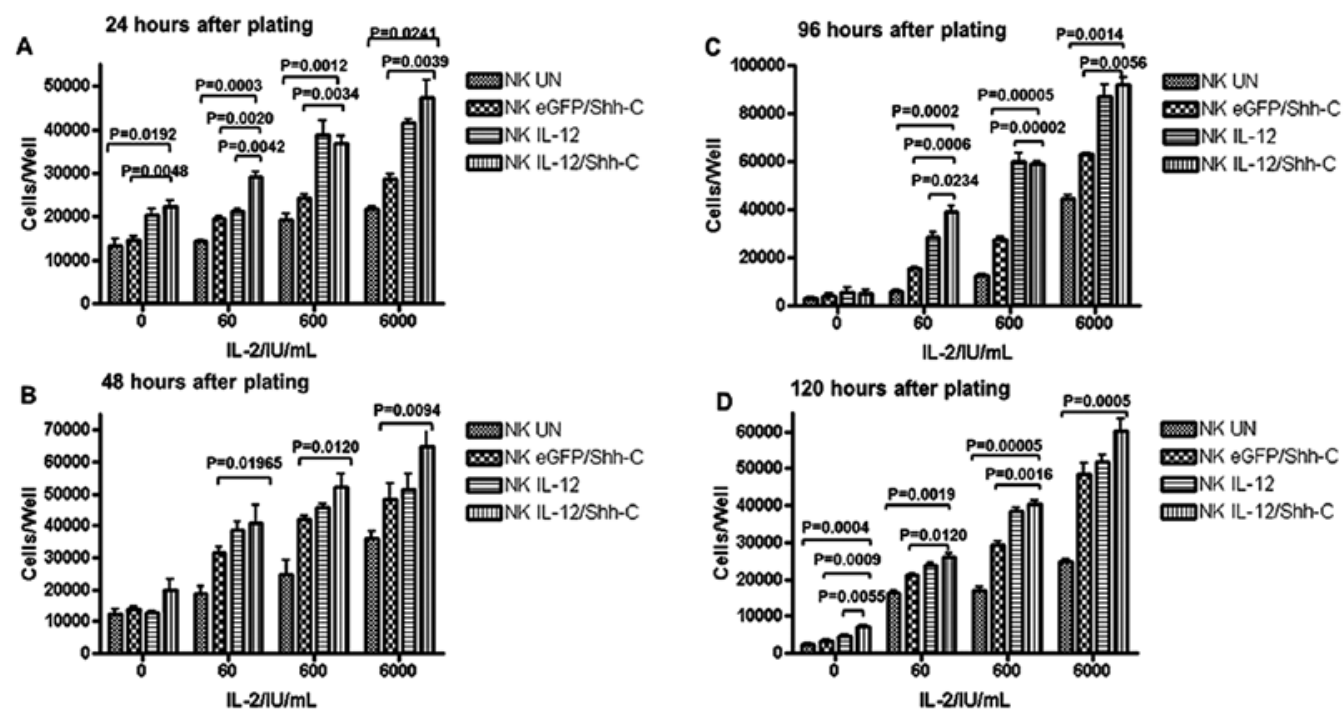

Figure 3. Proliferation of $\mathrm{NK}_{\mathrm{EGFP} / \mathrm{Shh}-\mathrm{C}}, \mathrm{NK}_{\mathrm{IL}-12}$ and $\mathrm{NK}_{\mathrm{IL}-12 / \mathrm{Shh}-\mathrm{C}}$ cells in the presence of different concentrations of IL-2 . (A-D) End-point data following 24, 48, 72 and 96 h of culture.

A

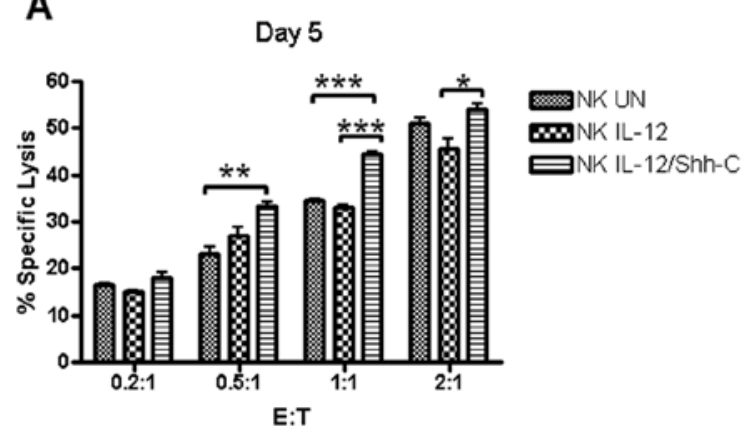

B

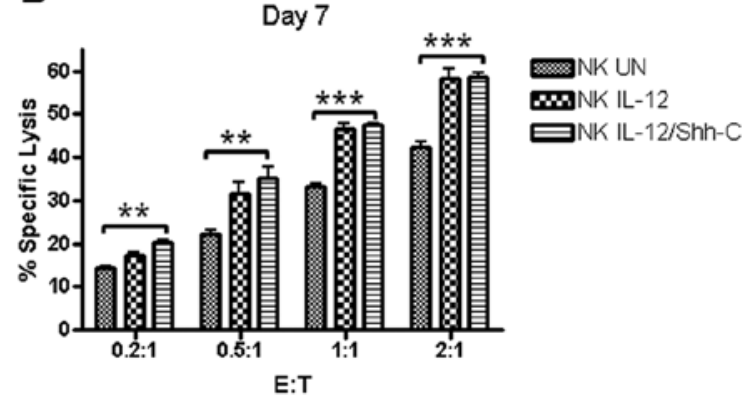

Figure 4. Cytotoxicity of $\mathrm{NK}_{\mathrm{UN}}, \mathrm{NK}_{\mathrm{IL}-12}$ and $\mathrm{NK}_{\mathrm{IL}-12 / \mathrm{Shh}-\mathrm{C}}$ cells. After 7 days of in vitro culture, NK cells were doubly-transduced (on days 7 and 8). Five and 7 days after the second transduction, NK cells were mixed with CFSE-coated YAC-1 cells at ratios of 2:1, 1:1, 0.5:1 and 0.2:1 and incubated for 4 h before the addition of 7-AAD. The specific lysis of YAC-1 cells measured by FACS is presented as a percentage. The data represent the averages of 3 independent experiments $\left({ }^{*} \mathrm{p}<0.05 ;{ }^{* *} \mathrm{p}<0.01 ;{ }^{* * *} \mathrm{p}<0.001\right)$.

to the untransduced NK cells on both days 7 and 9 after transduction. $\mathrm{NK}_{\mathrm{IL}-12 / \mathrm{Shh}-\mathrm{C}}$ cells had significantly lower CD25 expression compared to the $\mathrm{NK}_{\mathrm{IL}-12}$ and $\mathrm{NK}_{\mathrm{EGFP} / \mathrm{Sh} \text {-C }}$ cells (Fig. 5B). Perforin and granzyme $\mathrm{B}$ levels were also significantly higher in all lentivirus-transduced cells; however, granzyme B expression in $\mathrm{NK}_{\mathrm{IL}-12 / \mathrm{Shh}-\mathrm{C}}$ cells was significantly lower than that in $\mathrm{NK}_{\mathrm{IL}-12}$ cells $(\mathrm{p}=0.01349)$ or $\mathrm{NK}_{\mathrm{EGFP} / \mathrm{Shh}-\mathrm{C}}$ cells $(\mathrm{p}=0.01816)$. Additionally, significantly lower perforin production was observed in $\mathrm{NK}_{\mathrm{IL}-12 /}$ Shh-C cells when compared to $\mathrm{NK}_{\mathrm{IL}-12}$ cells $(\mathrm{p}=0.04784)$ (Fig. 5C and D).

Enhanced IFN- $\gamma$ and IL-12 production by IL-12/Shh-Cinfected NK cells. The cell culture supernatants were collected on the 5th and 7th day after double transduction and used for the measurements of IFN- $\gamma$ and IL-12 by ELISA. As shown in Fig. 6A and $\mathrm{B}, \mathrm{NK}_{\mathrm{IL}-12 / \mathrm{Shh}-\mathrm{C}}$ cells secreted significantly higher amounts of IFN- $\gamma$ on day $5(\mathrm{p}=0.00240)$ and even higher on day $7(\mathrm{p}=0.00121)$ than those secreted by $\mathrm{NK}_{\mathrm{IL}-12}$ cells. In addition, the IFN- $\gamma$ yield of $\mathrm{NK}_{\mathrm{IL}-12 / \mathrm{Shh}-\mathrm{C}}$ cells was also considerably higher than that of $\mathrm{NK}_{\mathrm{EGFP} / \mathrm{Shh}-\mathrm{C}}$ cells on both days $(\mathrm{p}<0.001)$.
The production of IL-12 was substantially higher by $\mathrm{NK}_{\mathrm{IL}-12 / \mathrm{Shh}-\mathrm{C}}$ cells compared to that by $\mathrm{NK}_{\mathrm{IL}-12}$ cells at 7 days after double transduction $(\mathrm{p}=0.01186)$. $\mathrm{NK}_{\mathrm{EGFP} / \mathrm{Shh}-\mathrm{C}}$ cells released significantly less IL-12 than $\mathrm{NK}_{\text {IL-12/Shh-C }}$ on both days $(\mathrm{p}<0.001)$.

Elevated plasma cytokine secretion in mice receiving adoptively transferred A-NK cells. Five million transduced or non-transduced NK cells from B6.PL-Thyla/CyJ mice were adoptively transferred into C57BL/6 mice i.v. challenged with B16 melanoma tumor cells 3 days earlier. Serum samples from mouse tail veins were collected on days 3, 7 and 14 after adoptive transfer. Mice which had received $\mathrm{NK}_{\mathrm{IL}-12 / \text { Shh-C }}$ cells showed significantly higher levels of TNF- $\alpha$ on days $3(\mathrm{p}=0.04410), 7(\mathrm{p}=0.03010)$ and $14(\mathrm{p}=0.00880)$ compared to the $\mathrm{B} 16$ only group, as shown in Fig. 7A. At 14 days after adoptive transfer, only mice which had received $\mathrm{NK}_{\mathrm{IL}-12 / \mathrm{Shh}-\mathrm{C}}$ cells showed a detectable level of IFN- $\gamma$ (Fig. 7B). The IL-12 level was significantly higher on day $7(\mathrm{p}=0.01898)$ in the mice which had received $\mathrm{NK}_{\mathrm{IL}-12 / \mathrm{Shh}-\mathrm{C}}$ cells compared with the mice which had received $\mathrm{NK}_{\mathrm{EGFP} / S h-\mathrm{C}}$ cells (Fig. 7B and C). 

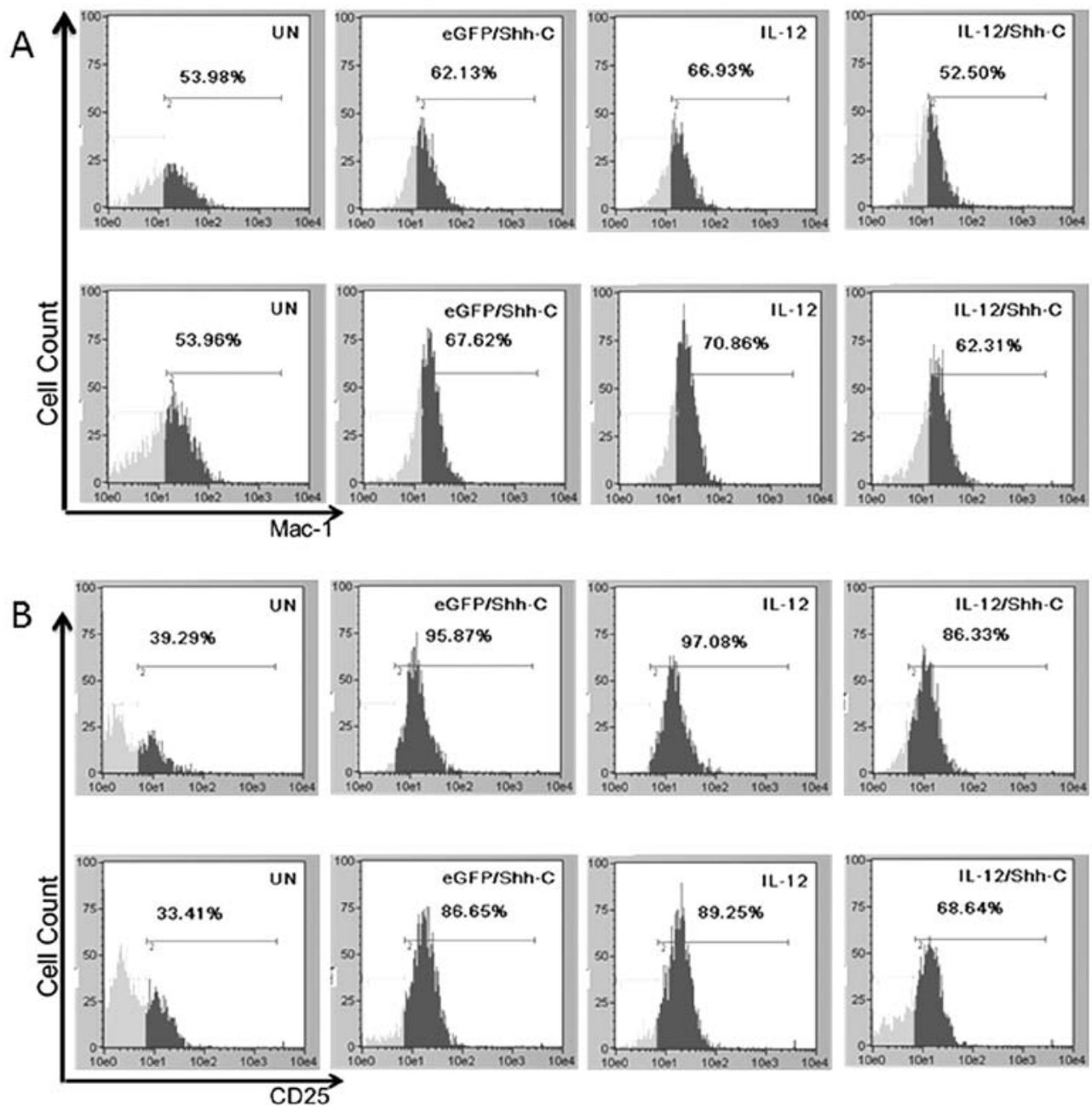

Figure 5. Phenotypic characterization of different lentivirus-transduced NK cells. NK cells were doubly-transduced on days 7 and 8 of in vitro culture. Seven and 9 days after lentivirus transduction, surface markers (Mac-1 and CD25) and intracellular markers (perforin and granzyme B) were analyzed by flow cytometry.

A
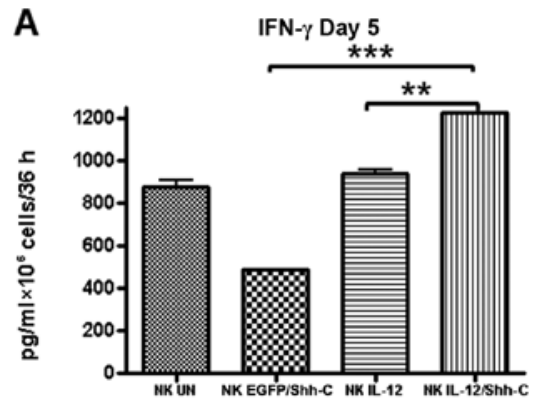

C

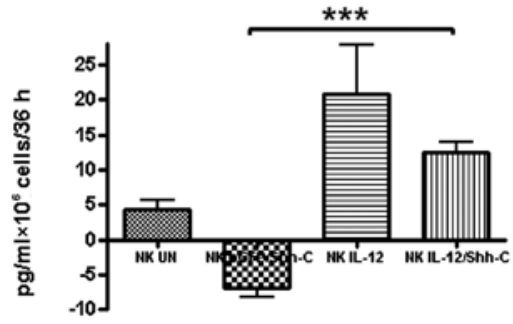

B

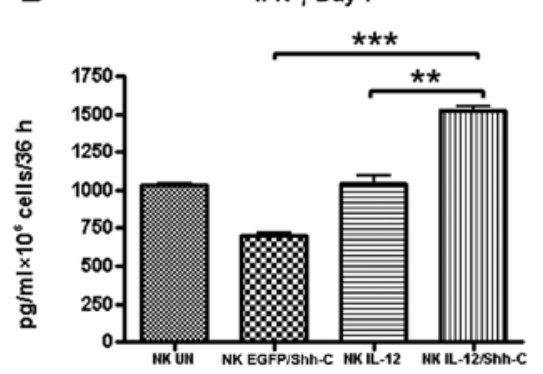

D

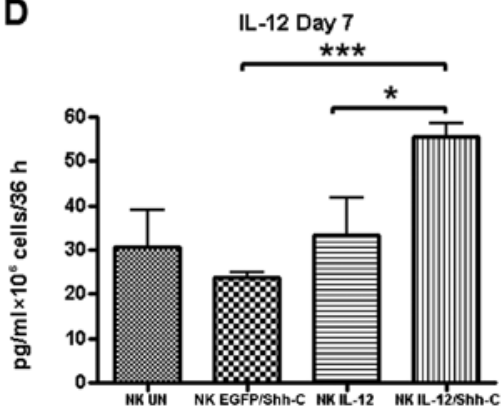

Figure 6. IFN- $\gamma$ and IL-12 production of $\mathrm{NK}_{\mathrm{EGFP} / \mathrm{Shh}-\mathrm{C}}, \mathrm{NK}_{\mathrm{IL}-12}$ and $\mathrm{NK}_{\mathrm{IL}-12 / \text { Shh-C }}$ cells. After 7 days of in vitro culture, NK cells were doubly-transduced on days 7 and 8 after in vitro culture. Cells were then cultured in the presence of $6,000 \mathrm{IU} / \mathrm{ml}$ of IL-2 for (A and C) 5 days or (B and D) 7 days. After another $36 \mathrm{~h}$ of culture, supernatant was collected from both cultures and cytokines were measured by ELISA. Results represent the means of 3 replicates $\pm \operatorname{SD}\left({ }^{*} \mathrm{p}<0.05 ;{ }^{* *} \mathrm{p}<0.01 ;{ }^{* * *} \mathrm{p}<0.001\right)$. 
A

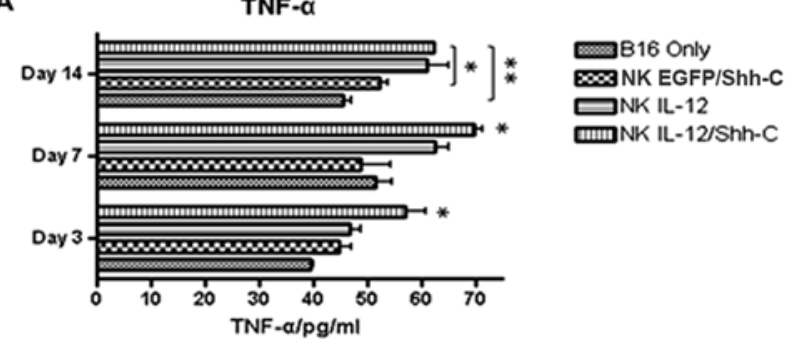

B

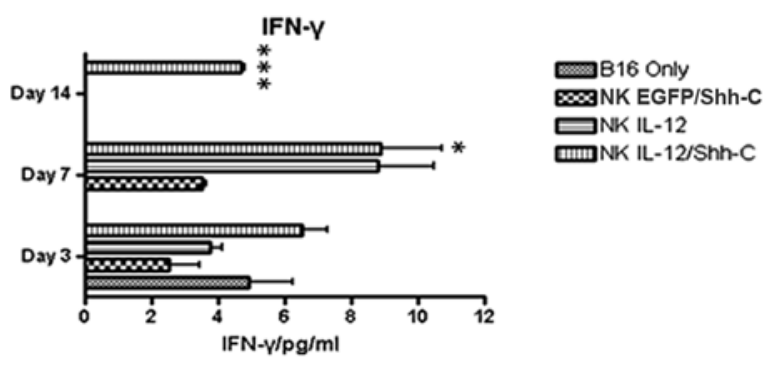

C

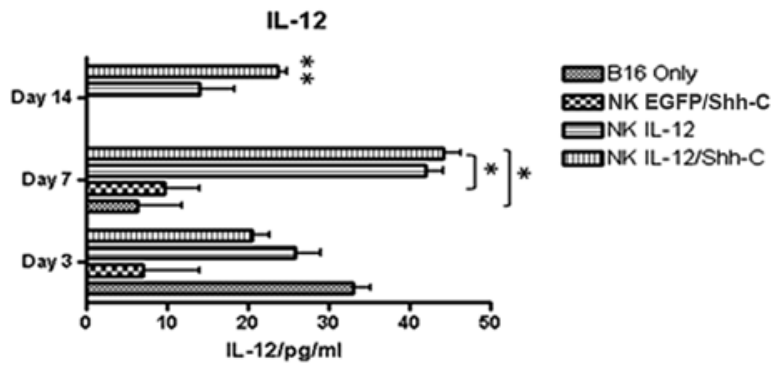

Figure 7. Cytokine levels in serum of B16 tumor-bearing mice which had received adoptively-transferred NK cells. C57BL/6 mice were injected with $3.75 \times 10^{5} \mathrm{~B} 16$ cells intravenously. Three days later, $5 \times 10^{6} \mathrm{NK}_{\mathrm{EGFPSSh}-\mathrm{C}}, \mathrm{NK}_{\mathrm{IL}-12}$ and $\mathrm{NK}_{\mathrm{IL}-12 / \mathrm{shh}-\mathrm{C}}$ cells were injected via the lateral tail vein without systemic IL-2 administration. Serum samples were collected from tails on days 3, 7 and 14 after adoptive NK cell transfer. Cytokine levels were determined by ELISA. Results represent the means \pm SD of 3 replicates ( $\left(\mathrm{p}<0.05 ;{ }^{* *} \mathrm{p}<0.01 ; * * \mathrm{p}<0.001\right)$.

A

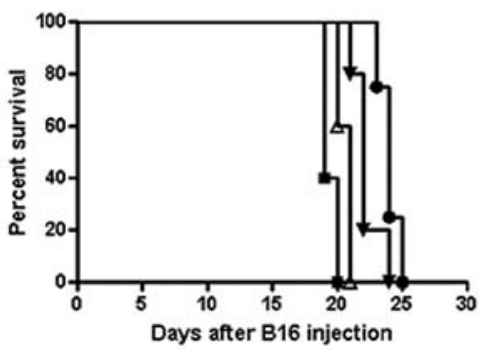

B

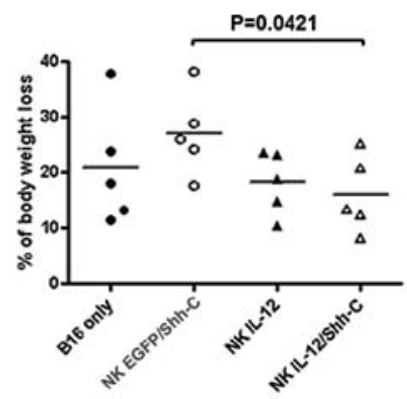

C

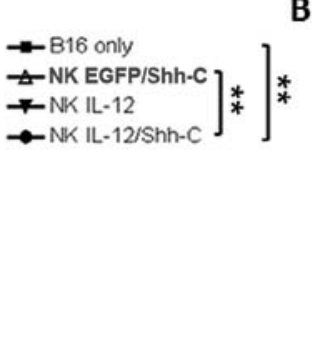

\section{3-day tumor, deep lung tissue}
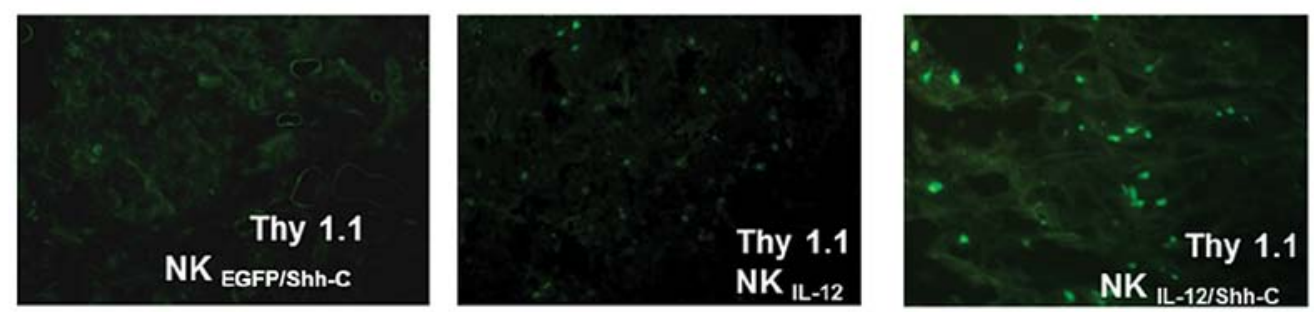

Figure 8. In vivo effects of lentivirus-transduced NK cells on B16 tumor-bearing mice. (A) Four groups (n=5) of C57BL/6 mice were intravenously injected with $3.75 \times 10^{5} \mathrm{~B} 16$ cells. Five million $\mathrm{NK}_{\mathrm{EGFP} / \mathrm{Sh}-\mathrm{C}}, \mathrm{NK}_{\mathrm{IL}-12}$ and $\mathrm{NK}_{\mathrm{IL}-12 / \mathrm{Shh}-\mathrm{C}}$ cells per mouse were injected via the lateral tail vein in 3 different groups 3 days later. Mice survival data were plotted using the Kaplan-Meier method and significant differences were determined by the log-rank test. (B) Total body weight loss of tumorbearing mice with NK cell adoptive transfer. (C) In vivo lung tissue infiltration by adoptively-transferred $\mathrm{NK}_{\mathrm{EGFPShh-C}}, \mathrm{NK}_{\mathrm{IL-12}}$ and $\mathrm{NK}_{\mathrm{IL}-1 / 2 / \mathrm{Shh}-\mathrm{C}}$ cells. Lung tissues were retrieved and sectioned $72 \mathrm{~h}$ after NK cell adoptive transfer. Donor NK cells were distinguished from recipients by staining with FITC-conjugated anti-mouse Thy 1.1 antibody.

Adoptively transferred NK cells infiltrate into lung tissue and prolong the survival time of tumor-bearing mice. Five million transduced or non-transduced NK cells from B6.PL-Thyla/ CyJ mice were adoptively transferred into C57BL/6 mice i.v. challenged with B16 melanoma tumor cells 3 or 10 days earlier without IL-2 systemic administration. Tumor-bearing mice which had received $\mathrm{NK}_{\mathrm{EGFP} / \mathrm{Sh} h-\mathrm{C}}, \mathrm{NK}_{\mathrm{IL}-12}$ and $\mathrm{NK}_{\mathrm{IL}-12 / \mathrm{Shh}-\mathrm{C}}$ cells all resulted in significantly higher overall survival rates than those of the B16 only mice ( $\mathrm{p}=0.0179, \mathrm{p}=0.0023$ and $\mathrm{p}=0.0052$, respectively; Fig. 8A). In addition, mice which had received 
$\mathrm{NK}_{\mathrm{IL}-12}$ and $\mathrm{NK}_{\mathrm{IL}-12 / \text { Shh-C }}$ cells showed significantly prolonged survival times than mice which had received $\mathrm{NK}_{\mathrm{EGFP} / S h-C}$ cells ( $\mathrm{p}=0.0116$ and $\mathrm{p}=0.0067$, respectively).

The localization of adoptively transferred NK cells in lung tissues with 3-day metastasized B16 tumor cells was examined at $72 \mathrm{~h}$ after adoptive transfer. Though no exogenous IL-2 injection was given, all groups of donor NK cells were found to be infiltrated into the deep lung tissues (Fig. 8B). More $\mathrm{NK}_{\mathrm{IL}-12 / \mathrm{Shh}-\mathrm{C}}$ cells were accumulated in the lung tissue indicated by the bigger and brighter fluorescent dots. However, when the late tumor model (10-day) was examined, donor NK cells were found to be difficult to target in the deep lung tissues (Fig. 8C).

\section{Discussion}

The immunogenicity of tumor cells is frequently suppressed by the down-regulation of major histocompatibility complex (MHC)-I and -II expression (25). On the contrary, the NK cell-mediated innate immune response does not require MHC for antigen presentation (26). Therefore, anti-tumor immune responses from NK cells would potentially be a great alternative to $\mathrm{T}$ cell-mediated immunotherapy for malignant tumors.

Two different approaches for the therapeutic use of NK cells have been exploited, including endogenous NK cell activation and adoptive transfer of in vitro activated autologous NK cells (27). For adoptive transfer, various animal studies have proven that autologous NK cell transfer is effective in tumor therapy (28). However, clinical trials have failed to meet the high expectations (29). One important contributing factor to the poor outcome in a clinical setting is the severe side-effects caused by IL-2 (30), which needs to be administered in very high doses to patients to ensure the survival and sustained activation of IL-2-A-NK cells. IL-12 has been shown to enhance the antitumor activity of NK cells while reducing their dependency on IL-2 (8). A fusion gene between mouse Shh-C auto-processing domain and IL-12 (IL-12/Shh-C) was designed in the present study as a self-supporting autocrine system aimed at reducing or eliminating the dependency of NK cells on exogenous IL-2 to sustain their activated status. The data from the present study show that $\mathrm{NK}_{\mathrm{IL}-12 / \mathrm{Shh}-\mathrm{C}}$ cells have a substantially faster growth rate compared to the $\mathrm{NK}_{\mathrm{UN}}$ and $\mathrm{NK}_{\text {EGPP/Shh-C }}$ cells, even in the absence of IL-2. However, IL-12 cannot be the sole driving force for NK cell survival in longterm cultures. The effect of IL-12 was most significant when IL-2 was added at low or medium levels. The $\mathrm{NK}_{\mathrm{IL}-12 / \mathrm{Shh}-\mathrm{C}}$ cells, when given $<10$-fold supplementation of IL-2, reached the same growth rate as $\mathrm{NK}_{\mathrm{EGFP} / \mathrm{Shh}-\mathrm{C}}$ cells. Also, the Mac-1 ${ }^{\text {hi }}$ cell population in $\mathrm{NK}_{\mathrm{IL}-1 / \text { Shh-C }}$ cells was not significantly higher than that in $\mathrm{NK}_{\mathrm{UN}}$ cells 7 days after double transduction, suggesting that $\mathrm{NK}_{\mathrm{IL}-12 / \mathrm{Sh}-\mathrm{C}}$ cells are less mature as a result of their significantly higher proliferation rate. However, after an additional 2 days in culture, the newly divided NK cells reached their maturation stage and the Mac- $1^{\text {hi }}$ cell percentage was substantially higher than the $\mathrm{NK}_{\mathrm{UN}}$ cells. Our results are in agreement with those from previous reports that only DX5 $5^{+} \mathrm{Mac}-1^{\text {low }}$ cells in the expansion stage have the potential to be proliferating NK cells. In addition, $\mathrm{NK}_{\mathrm{IL}-12 / \mathrm{Shh}-\mathrm{C}}$ cells had a significantly lower level of granzyme $\mathrm{B}$ expression than that of $\mathrm{NK}_{\mathrm{EGFP} / \mathrm{Sh}-\mathrm{C}}$ and $\mathrm{NK}_{\mathrm{IL}-12}$ cells, further suggesting that $\mathrm{NK}_{\mathrm{IL}-1 / / \mathrm{Shh}-\mathrm{C}}$ cells were less mature 7 days after double transduction.
When mouse lymphoma YAC-1 cells were used as a target, the cytotoxicities of $\mathrm{NK}_{\mathrm{IL}-12 / \mathrm{shh}-\mathrm{C}}$ cells 5 days after double transduction were significantly higher than those of $\mathrm{NK}_{\mathrm{UN}}$ cells only at E:T ratios of 1:1 and 0.5:1. In addition, 7 days after double transduction, significantly elevated cytotoxicities of both $\mathrm{NK}_{\mathrm{IL}-12 / \mathrm{Shh}-\mathrm{C}}$ cells were observed compared to $\mathrm{NK}_{\mathrm{UN}}$ cells at all E:T ratios. Furthermore, $\mathrm{NK}_{\mathrm{IL}-12 / \mathrm{Sh} h-\mathrm{C}}$ cells secreted significantly higher amounts of IFN- $\gamma$ on the 5th day and even higher on the 7th day than those of $\mathrm{NK}_{\mathrm{IL}-12}$ and $\mathrm{NK}_{\mathrm{EGFP} / \text { Shh-C }}$ cells. $\mathrm{NK}$ cell cytotoxicity is mediated through 3 different pathways: granule exocytosis pathway, death receptor pathway, and IFN- $\gamma$ mediated cytotoxicity (31). The present study shows that the enhanced cytotoxicity of $\mathrm{NK}_{\mathrm{IL}-12 / \mathrm{Shh}-\mathrm{C}}$ cells is mainly due to their increased secretion of cytotoxic cytokines, such as IFN- $\lambda$. Although perforin and granzyme B expressions were significantly higher in all lentivirus-transduced NK cells, the expression of these lytic molecules in $\mathrm{NK}_{\mathrm{IL}-12 / \text { shh-C }}$ cells was significantly lower than that in $\mathrm{NK}_{\mathrm{IL}-12}$ and $\mathrm{NK}_{\mathrm{EGFP} / \mathrm{Shh}-\mathrm{C}}$ cells.

The results from the current study showed that adoptively transferred NK cells effectively localized to lung tissues from mice which had received a tail vein injection of B16 tumor cells 3 days earlier. More $\mathrm{NK}_{\mathrm{IL}-12 / \mathrm{Sh}-\mathrm{C}}$ cells were accumulated in the lung tissues as indicated by the bigger and brighter fluorescent dots, presumably due to the accumulation of more $\mathrm{NK}_{\mathrm{IL}-12 / \mathrm{Sh}-\mathrm{C}}$ cells or the increased survival of the accumulated NK cells as a result of locally-accumulated IL-12. Substantially prolonged mice survival and significantly less total weight loss (data not shown) in mice were found following adoptive transfer of $\mathrm{NK}_{\mathrm{IL}-12 / \mathrm{Shh}-\mathrm{C}}$ cells when compared to mice with $\mathrm{NK}_{\mathrm{EGFP} / \text { Shh-C }}$ cell transfer, even in the absence of IL-2 systemic administration. Plasma cytokine analysis showed that the levels of TNF- $\alpha$ and IFN- $\lambda$ in the plasma of mice which had received adoptive transfers of $\mathrm{NK}_{\mathrm{IL}-12 / \mathrm{Shh}-\mathrm{C}}$ cells were significantly higher than those in the plasma of mice which had received $\mathrm{NK}_{\mathrm{EGFP} / \mathrm{Shh}-\mathrm{C}}$ or B16 tumor cells. Particularly on day 14 after the adoptive transfers of NK cells, only mice which had received $\mathrm{NK}_{\mathrm{IL}-1 / \text { /Shh-C }}$ cells showed a detectable level of IFN- $\gamma$. It has been suggested that elevated IFN- $\gamma$ and TNF- $\alpha$ levels are able to promote nitric oxide production to recruit macrophages to the tumor site. IFN- $\gamma$ was also able to up-regulate MHC class I expression to make target cells more susceptible to $\mathrm{T}$ cell-mediated immune response (32). Both IFN- $\gamma$ and TNF- $\alpha$ have been reported to up-regulate tumor antigen expression, thus making tumors more vulnerable to tumor-infiltrating lymphocyte killing. However, when NK cells were adoptively transferred 10 days after B16 tumor cell injection, very few adoptively transferred NK cells were detected in the deep lung tissue, suggesting that it is very difficult for the adoptively transferred NK cells to penetrate into the tumor mass at this stage. B16 metastases have been documented to be divided into loose and compact types morphologically (8). The compact metastases have several-fold less expression of chemoattractive proteins and they also lack microvascular networks compared to the loose type. These unique features of late tumor tissues may partially explain the inability of NK cells to infiltrate into late tumor tissues.

Local or regional treatment eliminates the systemic adverse reactions caused by soluble cytokines. Previous studies have suggested that the efficiency of the delivery of cytokines into the plasma membrane can be elevated through the reanchoring of GPI-anchored proteins onto neighboring cells (14). With the 
current strategy, IL-12 with a cholesterol tail would not only anchor to the membrane, but also diffuse into the near vicinity of the producing NK cells to form a concentration gradient. Although the secreted IL-12 level is low, as it can only be detected by ELISA, and not western blot analysis, it should be enough to act on other NK cells or immune cells coming into the gradient range, and would thus have more far reaching effects than just the producing cell alone.

\section{References}

1. Moretta A, Bottino C, Mingari MC, Biassoni R and Moretta L: What is a natural killer cell? Nat Immunol 3: 6-8, 2002.

2. Smyth MJ,Thia KY, Cretney E, et al: Perforin is a major contributor to NK cell control of tumor metastasis. J Immunol 162: 6658-6662, 1999.

3. Lauwerys BR, Garot N, Renauld JC, and Houssiau FA: Cytokine production and killer activity of NK/T-NK cells derived with IL-2, IL-15, or the combination of IL-12 and IL-18. J Immunol 165 1847-1853, 2000.

4. Smith BR, Rosenthal DS and Ault KA: Natural killer lymphocytes in hairy cell leukemia: presence of phenotypically identifiable cells with defective functional activity. Exp Hematol 13: 189-193, 1985.

5. Biron CA, Nguyen KB, Pien GC, Cousens LP and SalazarMather TP: Natural killer cells in antiviral defense: function and regulation by innate cytokines. Annu Rev Immunol 17:189-220, 1999.

6. Rosenberg S: Lymphokine-activated killer cells: a new approach to immunotherapy of cancer. J Natl Cancer Inst 75: 595-603, 1985

7. Trinchieri G, Matsumoto-Kobayashi M, Clark SC, Seehra J, London L and Perussia B: Response of resting human peripheral blood natural killer cells to interleukin 2. J Exp Med 160 1147-1169, 1984

8. Goding SR, Yang Q, Knudsen KB, Potter DM and Basse PH: Cytokine gene therapy using adenovirally transduced, tumorseeking activated natural killer cells. Hum Gene Ther 18: 701-711, 2007.

9. Rosenberg SA, Lotze MT, Muul LM, et al: Observations on the systemic administration of autologous lymphokine-activated killer cells and recombinant interleukin-2 to patients with metastatic cancer. N Engl J Med 313: 1485-1492, 1985.

10. Yang Q, Hokland ME, Bryant JL, et al: Tumor-localization by adoptively transferred, interleukin-2-activated NK cells leads to destruction of well-established lung metastases. Int J Cancer 105: 512-519, 2003.

11. Loza MJ and Perussia B: The IL-12 signature: NK cell terminal CD56 ${ }^{+}$high stage and effector functions. J Immunol 172: 88-96, 2004.

12. Maas RA, Dullens HF and Den Otter W: Interleukin-2 in cancer treatment: disappointing or (still) promising? A review. Cancer Immunol Immunother 36: 141-148, 1993.
13. Imboden M, Shi F, Pugh TD, et al: Safety of interleukin-12 gene therapy against cancer: a murine biodistribution and toxicity study. Hum Gene Ther 14: 1037-1048, 2003.

14. Ji J, Li J, Holmes LM, et al: Glycoinositol phospholipid-anchored interleukin 2 but not secreted interleukin 2 inhibits melanoma yumor growth in mice. Mol Cancer Ther 1: 1019-1024, 2002.

15. Konstantinidis KV, Alici E, Aints A, Christensson B, Ljunggren HG and Dilber MS: Targeting IL-2 to the endoplasmic reticulum confines autocrine growth stimulation to NK-92 cells. Exp Hematol $33: 159-164,2005$.

16. Gurdon JB and Bourillot PY: Morphogen gradient interpretation. Nature 413: 797-803, 2001.

17. Cadigan KM: Regulating morphogen gradients in the Drosophila wing. Semin Cell Dev Biol 13: 83-90, 2002.

18. Lawrence PA and Struhl G: Morphogens, compartments, and pattern: lessons from Drosophila? Cell 85: 951-961, 1996.

19. Tabata T and Kornberg TB: Hedgehog is a signaling protein with a key role in patterning Drosophila imaginal discs. Cell 76: 89-102, 1994.

20. Teleman AA, Strigini M and Cohen SM: Shaping morphogen gradients. Cell 105: 559-562, 2001.

21. Vincent JP and Dubois L: Morphogen transport along epithelia, an integrated trafficking problem. Dev Cell 3: 615-623, 2002.

22. Mann RK and Beachy PA: Novel lipid modifications of secreted protein signals. Annu Rev Biochem 73: 891-923, 2004.

23. Guerrero I and Chiang C: A conserved mechanism of Hedgehog gradient formation by lipid modifications. Trends Cell Biol 17: 1-5, 2007.

24. Vincent S, Thomas A, Brasher B and Benson JD: Targeting of proteins to membranes through hedgehog auto-processing. Nat Biotechnol 21: 936-940, 2003.

25. Sanda MG, Restifo NP, Walsh JC, et al: Molecular characterization of defective antigen processing in human prostate cancer. J Natl Cancer Inst 87: 280-285, 1995.

26. Robertson MJ and Ritz J: Biology and clinical relevance of human natural killer cells. Blood 76: 2421-2438, 1990.

27. Albertsson PA, Basse PH, Hokland M, et al: NK cells and the tumour microenvironment: implications for NK-cell function and anti-tumour activity. Trends Immunol 24: 603-609, 2003.

28. Basse PH, Whiteside TL and Herberman RB: Cancer immunotherapy with interleukin-2-activated natural killer cells. Mol Biotechnol 21: 161-170, 2002.

29. Law TM, Motzer RJ, Mazumdar M, et al: Phase III randomized trial of interleukin-2 with or without lymphokine-activated killer cells in the treatment of patients with advanced renal cell carcinoma. Cancer 76: 824-832, 1995.

30. Kammula US, White DE and Rosenberg SA: Trends in the safety of high dose bolus interleukin-2 administration in patients with metastatic cancer. Cancer 83: 797-805, 1998.

31. Herberman RB, Reynolds CW and Ortaldo JR: Mechanism of cytotoxicity by natural Killer (NK) cells. Annu Rev Immunol 4: 651-680, 1986.

32. Skoskiewicz MJ, Colvin RB, Schneeberger EE and Russell PS: Widespread and selective induction of major histocompatibility complex-determined antigens in vivo by gamma interferon. J Exp Med 162: 1645-1664, 1985. 